\title{
Making the Most of Our Land: Managing Soil Functions from Local to Continental Scale
}

\section{OPEN ACCESS}

Edited by:

Maria Tsiafouli,

Aristotle University of Thessaloniki,

Greece

Reviewed by:

Ângela Cristina Lomba

Research Centre in Biodiversity and

Genetic Resources, Portugal Holger Hoffmann,

Leibniz Universität Hannover, Germany

*Correspondence:

Rogier P. O. Schulte rogier.schulte@teagasc.ie

Specialty section:

This article was submitted to Agroecology and Land Use Systems,

a section of the journal

Frontiers in Environmental Science

Received: 31 August 2015 Accepted: 04 December 2015 Published: 22 December 2015

Citation:

Schulte RPO, Bampa F, Bardy M, Coyle C, Creamer RE, Fealy $R$, Gardi C, Ghaley BB, Jordan P, Laudon H, O'Donoghue $C$,

ÓhUallacháin D, O’Sullivan L,

Rutgers M, Six J, Toth GL and Vrebos D (2015) Making the Most of

Our Land: Managing Soil Functions from Local to Continental Scale.

Front. Environ. Sci. 3:81.

doi: 10.3389/fenvs.2015.00081

\author{
Rogier P. O. Schulte $1,2 *$, Francesca Bampa ${ }^{1}$, Marion Bardy ${ }^{3}$, Cait Coyle ${ }^{4}$, \\ Rachel E. Creamer ${ }^{1}$, Reamonn Fealy ${ }^{5}$, Ciro Gardi ${ }^{6}$, Bhim Bahadur Ghaley ${ }^{7}$, Phil Jordan ${ }^{8}$, \\ Hjalmar Laudon ", Cathal O'Donoghue ${ }^{10}$, Daire Ó'hUallacháin ', Lilian O'Sullivan ', \\ Michiel Rutgers ${ }^{11}$, Johan Six ${ }^{12}$, Gergely L. Toth ${ }^{13}$ and Dirk Vrebos ${ }^{14}$ \\ ${ }^{1}$ Crops, Environment and Land Use Programme, Teagasc, Wexford, Ireland, ${ }^{2}$ Latvia University of Agriculture, Jelgava, Latvia, \\ ${ }^{3}$ Institut National de la Recherche Agronomique, US1106 InfoSol, Orleans, France, ${ }^{4}$ Department of Environmental Science, \\ Institute of Technology Sligo, Sligo, Ireland, ${ }^{5}$ Rural Economy and Development Programme, Teagasc, Ashtown, Ireland, \\ ${ }^{6}$ European Food Safety Authority, Parma, Italy, ${ }^{7}$ Department of Plant and Environmental Sciences, Faculty of Science, \\ University of Copenhagen, Taastrup, Denmark, ${ }^{8}$ Environmental Sciences Research Institute, University of Ulster, Coleraine, \\ UK, ${ }^{9}$ Department of Forest Ecology and Management, Swedish University of Agricultural Sciences (SLU), Umeå, Sweden, \\ ${ }^{10}$ Rural Economy and Development Programme, Athenry, Ireland, ${ }^{11}$ Centrum Duurzaamheid, Milieu en Gezondheid, \\ Rijksinstituut voor Volksgezondheid en Milieu, Bilthoven, Netherlands, ${ }^{12}$ Department of Environmental Systems Science, \\ ETHZ, Zurich, Switzerland, ${ }^{13}$ Joint Research Centre of the European Commission, Institute for Environment and \\ Sustainability, Ispra, Italy, ${ }^{14}$ Department of Biology, University of Antwerp, Antwerp, Belgium
}

The challenges of achieving both food security and environmental sustainability have resulted in a confluence of demands on land within the European Union (EU): we expect our land to provide food, fiber and fuel, to purify water, to sequester carbon, and provide a home to biodiversity as well as external nutrients in the form of waste from humans and intensive livestock enterprises. All soils can perform all of these five functions, but some soils are better at supplying selective functions. Functional Land Management is a framework for policy-making aimed at meeting these demands by incentivizing land use and soil management practices that selectively augment specific soil functions, where required. Here, we explore how the demands for contrasting soil functions, as framed by EU policies, may apply to very different spatial scales, from local to continental scales. At the same time, using Ireland as a national case study, we show that the supply of each soil function is largely determined by local soil and land use conditions, with large variations at both local and regional scales. These discrepancies between the scales at which the demands and supply of soil functions are manifested, have implications for soil and land management: while some soil functions must be managed at local (e.g., farm or field) scale, others may be offset between regions with a view to solely meeting national or continental demands. In order to facilitate the optimization of the delivery of soil functions at national level, to meet the demands that are framed at continental scale, we identify and categorize 14 policy and market instruments that are available in the EU. The results from this inventory imply that there may be no need for the introduction of new specific instruments to aid the governance of Functional Land Management. We conclude that there may be more merit in adapting existing governance instruments by facilitating differentiation between soils and landscapes.

Keywords: Functional Land Management, ecosystem services, policy, soil functions, sustainable intensification 


\section{INTRODUCTION}

\section{Context: Demands on Land}

In 2014, the United Nations (UN) revised their projections for population growth: the world's population is no longer expected to stabilize after 2050, but is now forecast to continue to grow and approach 11 billion people by 2100 (Gerland et al., 2014). These figures will certainly fuel the debate on whether the world is "running out of land" (Keesstra et al., 2015). Indeed, the UN Food and Agriculture Organisation (FAO) estimate that the world may need to increase food production by $60 \%$ over the period 2005 2050 , in order to feed a predicted population of more than nine billion (Alexandratos and Bruinsma, 2012).

However, not only do we expect the world's agricultural land to provide a nutritious diet for all, we also expect it to secure clean water, to sequester and store carbon, to host biodiversity and provide a home for our organic waste (Montanarella and Vargas, 2012; Schulte et al., 2014). At the same time, the required increase in agricultural productivity is projected to add further stress to the availability and usage of these ecosystem services. For example, agricultural greenhouse gas (GHG) emissions currently account for $10-12 \%$ of global GHG emissions (Smith et al., 2007). The Organisation for Economic Cooperation and Development (OECD) projects that agricultural emissions of methane and nitrous oxide will increase in absolute terms, in tandem with increased agricultural production, whilst carbon dioxide emissions arising from land use changes are projected to fall (Marchal et al., 2012).

In addition, agriculture is the world's largest user of freshwater, accounting for $70 \%$ of global freshwater use (Evans, 2009), although there are large differences in water use between regions and farming systems. A large proportion of the projected increase in global agricultural production is likely to be derived through new irrigation initiatives; the FAO estimates that irrigation will increase by $11 \%$, predominantly in areas with precipitation deficits (Bruinsma, 2009). This increase will most likely have negative consequences for local groundwater or riverine water balances where over-abstraction occurs. This may be further exacerbated by climate change: for example, Zhao et al. (2015) modeled irrigation requirements across Europe for six major crops under climate change scenarios, and predicted increased requirements for drier regions. In moister regions of Europe, the interface between agriculture and water is predominantly defined by the impact of farming on the quality of drinking water and the ecological quality of connected water bodies (Withers and Haygarth, 2007). Here, the prevention of eutrophication, caused by excess nutrient losses from land to water, represents one of the main challenges to sustainability (e.g., Schulte et al., 2006).

The relationship between agriculture and biodiversity is complex: occupying $38 \%$ of the world's land surface (FAOSTAT, 2013), agriculture simultaneously provides habitats for biodiversity and competes for space with non-agricultural ecological habitats (FAO, 2015). If increased food production were to be achieved through an expansion of land area used for agriculture, this would pose challenges to the preservation of ecological habitats and their associated biodiversity. However, a sole reliance on "intensification" could equally pose challenges to species and habitats associated with land currently used for extensive agricultural production (e.g., Robinson and Sutherland, 2002; Tscharntke et al., 2005).

The magnitude and complexities of these interrelated challenges are such that no less than six of the 17 Sustainable Development Goals of the United Nations (http://sustainabledevelopment.un.org/) are devoted, either directly or indirectly, to the sustainable management of land, namely:

- Goal 2: End hunger, achieve food security and improved nutrition, and promote sustainable agriculture;

- Goal 6: Ensure availability and sustainable management of water and sanitation for all;

- Goal 7: Ensure access to affordable, reliable, sustainable, and modern energy for all;

- Goal 12: Ensure sustainable consumption and production patterns;

- Goal 13: Take urgent action to combat climate change and its impacts;

- Goal 15: Protect, restore and promote sustainable use of terrestrial ecosystems, sustainably manage forests, combat desertification, and halt and reverse land degradation and halt biodiversity loss.

These multiple and interrelated challenges have given rise to a situation where land is becoming an increasingly constrained natural resource, particularly in the context of land degradation through erosion (Ye and Van Ranst, 2009; Sauer et al., 2011) and soil sealing, with the latter being responsible for a "loss" of about 20 million ha of agricultural soils each year (Nachtergaele et al., 2011). This necessitates prudent management from the local to continental and indeed global scale. The urgency of this need is exemplified by recent concerns about "land grabbing," i.e., the process where land in a country is "secured" by investors to produce primary goods commonly destined for other jurisdictions (see Cotula et al., 2009, for a balanced review). These concerns on the finite nature of land as a resource have now brought the significance of soil science sharply back into focus.

\section{Managing Soil Functions}

In 2006, the European Commission published the EU Thematic Strategy for Soil Protection (European Commission, 2006a), which outlined the suite of functions that soils perform for humankind, as well as the threats to this functionality. The subsequent proposal for a Soil Framework Directive (European Commission, 2006b) built on the concept of threats to soil quality, which included erosion, contamination, loss of organic matter, loss of biodiversity, compaction, salinization, flooding, landslides, and sealing. The Directive proposed a suite of actions to mitigate against these threats, aimed at maintaining soil quality throughout the EU. However, this exclusive focus on threats, while only hinting at soil quality as a prerequisite of the utility function of soils, led to resistance from stakeholders, including the farming community (COPA-COGECA, 2008). This, as well as a multitude of unrelated political considerations, ultimately 
resulted in the withdrawal of the proposed Directive in 2014 as part of the EU REFIT initiative (European Commission, 2014).

However, these developments have not reduced the urgent need to explore how we can safeguard our land resource for the provision of food and other ecosystem services (Maes et al., 2012). Indeed, in 2014 the Commission stated that it remains committed to the objective of the protection of soil and will examine options on how to best achieve this. This commitment is reflected in the 2011 Resource Efficiency Road Map-Europe 2020 Strategy. As part of this strategy, EU policies must account for their direct and indirect impact on land use in Europe and globally by 2020. Responding to the Road Map, the European Commission is working on a Communication on "Land as a resource," that will provide a new framework for sustainable and appropriate land management across the EU. This Communication is aimed at (a) accelerating actions in the context of valuing land as a resource for ecosystem services, (b) filling the gap between demand and availability of land, and (c) setting synergies and trade-offs between competing land uses and functions (Deloitte, 2014).

To inform this process, Schulte et al. (2014) proposed "Functional Land Management" as a more utilitarian framework, aimed at optimizing the delivery of five main soil functions (Figure 1):

(1) Primary productivity: the provision of food, feed, fiber and fuel;

(2) Water purification and regulation: the ability of soils to purify and regulate water for human consumption and maintenance of ecosystem integrity;

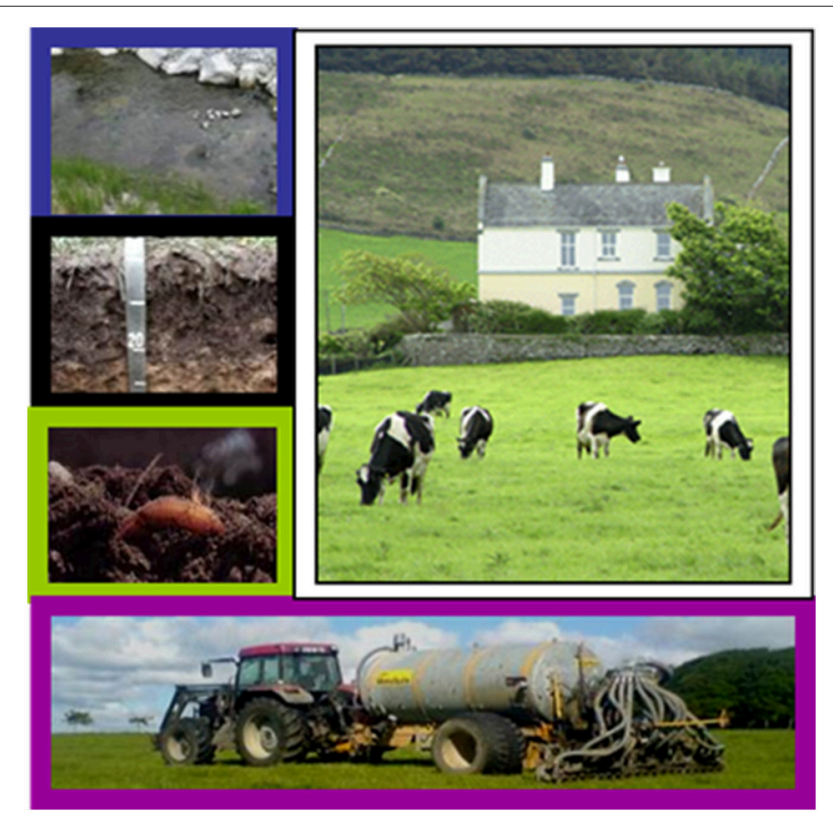

FIGURE 1 | Illustrative representation of the suite of five soil functions proposed by Schulte et al. (2014). The white box indicates primary production; blue, water purification and regulation; black, carbon storage and regulation; green, provision of a habitat for biodiversity; purple, cycling of nutrients.
(3) Carbon storage and regulation: the ability of soils to store carbon for (a) partial offsetting of GHG emissions and (b) regulation of biological and physical soil processes;

(4) Provision of a habitat for biodiversity, both below-ground and above-ground diversity;

(5) Cycling and provision of nutrients, specifically the ability of soils to provide a sustainable home for external nutrients such as those derived from landless farming systems (e.g., pig and poultry farms), as well as sewage sludge and other organic waste products.

Intrinsically, all soils can perform all of these functions, but some soils are better at some functions than others (e.g., Ghaley et al., 2015). The relative suite of functions depends primarily on land use and management, and an indicative illustration of this dependency was provided in the original paper (Schulte et al., 2014). In addition, the relative supply of each soil function depends on soil properties. For example, in Atlantic climates, soil drainage is the predominant soil property that defines the functionality of soils (Schulte et al., 2012). Using this pedoclimatic zone (based on the delineation by Metzger et al., 2005) as a case study, the interdependencies between soil functions, land use and drainage were explored in detail by Coyle et al. (2015), who developed conceptual models for each of the soil functions, culminating in a matrix that illustrates the relative ability of contrasting soils and land use combinations to supply each of the five soil functions (Figure 2).

Functional Land Management aims to optimize, rather than maximize, the supply of each of the soil functions in order to meet the societal demands for all five functions simultaneously. In the original paper, Schulte et al. (2014) illustrated this by assessing the supply and demand for the five soil functions at a national scale, using Ireland as a case-study. However, they noted that this national assessment "masked" significant variation, both in the supply and demand for individual soil functions at local scales, and was therefore not yet fit-for-purpose to inform policy making. Therefore, there is a need to assess the spatial scale at which both the demand for, and the supply of each soil function applies.

\section{Objective}

Therefore, with a view to informing the forthcoming EU Communication on Land as a Resource, the objective of this paper is two-fold:

(1) First, we explore the spatial variability and patterns of the supply of each of the five soil functions, using Ireland as a national example. We subsequently assess the spatial scale at which each of the demands for these soil functions apply, from the local scale to national or continental scale.

(2) Secondly, we examine the options for governance of Functional Land Management, specifically how the supply of soil functions can be managed to meet the multitude of demands, as framed by EU policies. We make an inventory of policy and market instruments that are available for governance, and bring these together into a framework for policy-making that guides and connects decision making across spatial scales. 


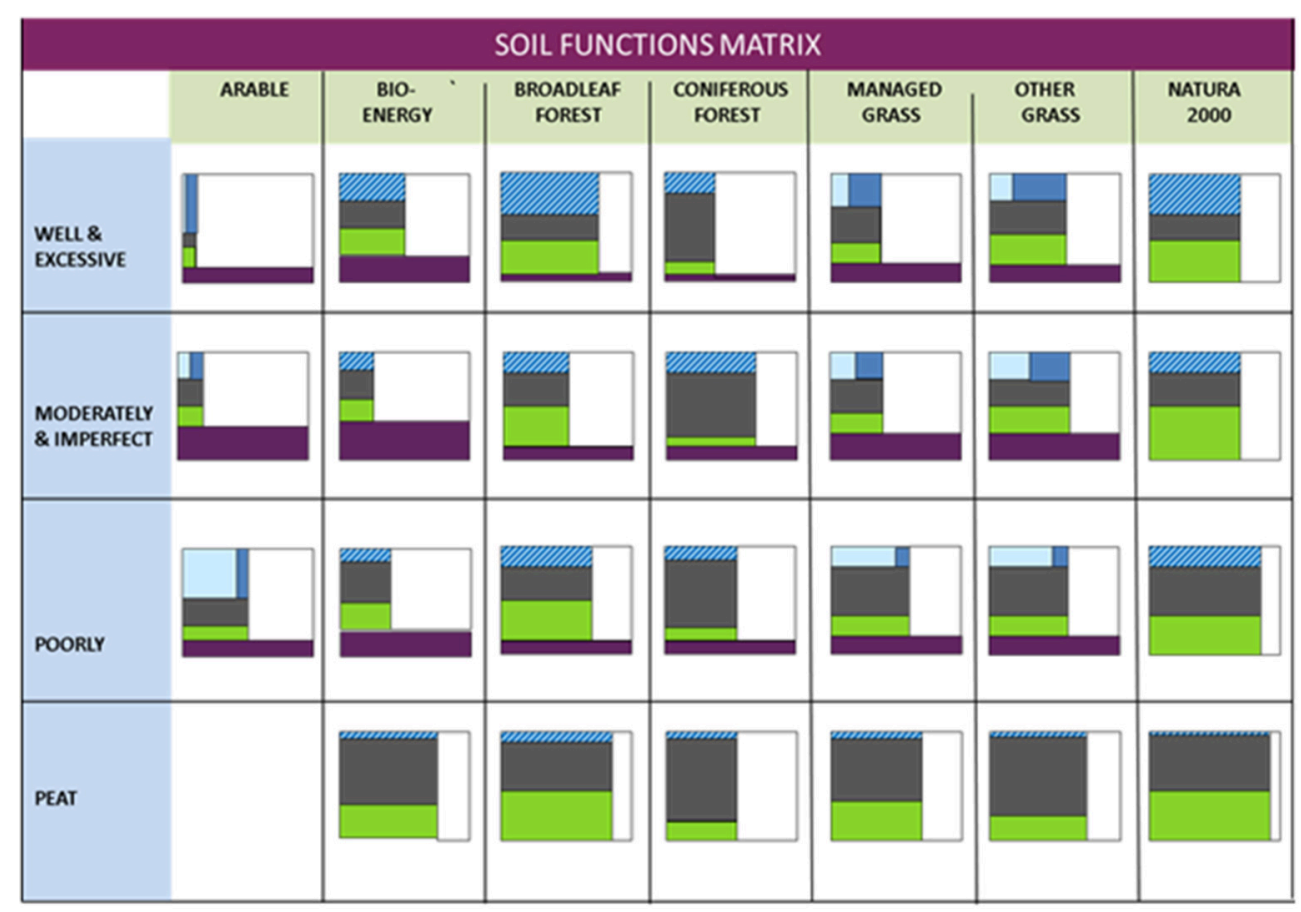

FIGURE 2 | Soil Functions Matrix (adapted from Coyle et al., 2015) illustrating the supply of the five soil functions (the size of the five boxes) in relation to land use (horizontal axis) and soil drainage (vertical axis). White boxes indicate primary production; blue, water purification and regulation; black, carbon storage and regulation; green, provision of a habitat for biodiversity; purple, cycling of nutrients.

\section{MATERIALS AND METHODS}

\section{Supply of Soil Functions}

To quantify the spatial variation in the supply of each of the five soil functions in Ireland, we used the partial proxy-indicators previously published by Schulte et al. (2014) and Coyle et al. (2015) for Atlantic climates. These were: (i) carrying capacity for primary productivity; (ii) denitrification capacity for water purification; (iii) potential carbon sequestration; (iv) habitat type in relation to species richness, abundance and biomass, and (v) the capacity to sustainably process slurry from pig farms and/or sewage sludge for the function nutrient cycling.

To facilitate mapping of the supply of soil functions, we intersected the new 1:250,000 Indicative Soil Drainage Map of Ireland (Schulte et al., 2015) with the 1:250,000 Land Use Map of Ireland (O'Sullivan et al., 2015), in order to derive a map of combinations of land use and drainage, equivalent to those used in Figure 2 above. The Soil Drainage Map was based on the new 3rd generation 1:250,000 Soil Map of Ireland (Creamer et al., 2014). For each of the five functions, we calculated z-scores (Wagg et al., 2014) to derive a normalized weighting for each combination of land use and drainage category, based on the relative proportionalities of Figure 2.

\section{Demands for Soil Functions}

In order to assess spatial variation in the demand for each of the soil functions, we first conducted a policy review to frame these demands, as defined by EU policies. In the absence of a Soil
Framework Directive, there is no single overarching EU policy that comprehensively defines the demand for each of the soil functions. Instead, this demand is framed by a large number of EU policies. Figure 3 lists the most pertinent of these policies, the associated soil functions of relevance, and the spatial scale to which each policy applies. We then defined (partial) proxyindicators for each of these demands. The selection of these proxy-indicators was guided by the availability of spatial data.

The main EU policy driver for increased primary productivity in an Irish context is the abolition of the milk quota in 2015, as part of the new Common Agricultural Policy (CAP). This is of particular relevance to Irish farming, where many dairy farms have hitherto been constrained by quota rather than by land. Food Harvest 2020 (Department of Agriculture, Food and the Marine, 2010) is the industry strategy, supported by the Irish Government, to grow the agricultural sector, with a specific emphasis on increasing the volume of national milk output by $50 \%$ in the period 2015-2020. This ambitious volume target for the dairy sector is currently framing the demand for increased primary productivity. As most of the new volume is derived from existing dairy farms, rather than from new entrants (pers. comm. S. Molloy, Director of Strategy, Glanbia), we chose the density of dairy cows per District Electoral Division as the proxy-indicator for the spatial patterns of the demand for increased primary productivity.

The Nitrates Directive (EU, 1991) is currently the main policy that frames the demand for denitrification, as it requires groundwater nitrate concentrations to remain below $50 \mathrm{mg} \mathrm{l}^{-1}$. 


\begin{tabular}{|c|c|c|}
\hline EU Policy Driver & Function(s) of relevance ${ }^{l}$ & Scale at which demand is framed \\
\hline Common Agricultural Policy (CAP) & $\mathrm{P}$ & EU \\
\hline Areas of Natural Constraint (ANC) & $\mathrm{P}$ & EU/National \\
\hline Greening Measures & $\mathrm{C} \mathrm{H}$ & Ubiquitous \\
\hline Nitrates Directive & $\mathrm{W}$ & Ubiquitous / Regional \\
\hline Water Framework Directive & $\mathrm{W}$ & River Basin District \\
\hline Habitat \& Birds Directive & $\mathrm{H}$ & Multiple scales \\
\hline Agri-Environmental Schemes & $\mathrm{W} \mathrm{C}$ & Farm/regional \\
\hline EU 2030 Climate and Energy Framework & C & EU + National targets \\
\hline Sewage Sludge Directive & $\mathrm{N}$ & Regional \\
\hline \multicolumn{3}{|c|}{$\mathrm{P}=$ primary productivity, $\mathrm{W}=$ water purification, $\mathrm{C}=$ carbon sequestration, $\mathrm{H}=$ habitat provision, $\mathrm{N}=$ nutrient cycling } \\
\hline
\end{tabular}

FIGURE 3 | Inventory of EU policy drivers that frame the demand for the five soil functions (illustrated by the colored boxes), and the spatial scale to which each of these policies applies.

This is enforced throughout the EU by imposing a maximum annual application rate of organic nitrogen at $170 \mathrm{~kg} \mathrm{~N} \mathrm{ha}^{-1}$ (equivalent to the annual excretion from $c$. two livestock units (LSU) per hectare) in nitrate vulnerable zones (NVZs). Ireland is one of the MS that has adopted a "whole-territory approach" to the concept of NVZs, which means that the restrictions apply to all farms throughout the country. Ireland currently has a derogation that allows for stocking rates up to $250 \mathrm{~kg} \mathrm{~N} \mathrm{ha}^{-1}$, where farmers implement a field-level nutrient management plan based on soil analysis (Government of Ireland, 2009). In this context, we chose stocking rate as the proxy-indicator that frames the policy demand for denitrification.

The demand for carbon sequestration and regulation is framed by two policies: (1) the "Greening Requirements" under Pillar 1 of the CAP and (2) the EU Climate and Energy Framework 2030. The Greening Requirements require, inter alia, that soil organic carbon contents are maintained in excess of $2 \%$ (Department of Agriculture, Food and the Marine, 2009; Spink et al., 2010) with a dual purpose of maintaining soil quality and preventing GHG emissions in the form of carbon dioxide. However, this latter objective is likely to be addressed more comprehensively in the EU Climate and Energy Framework for 2030. This framework is on track to depart from its predecessor (the Climate and Energy Package 2020), in that it is likely to allow for the Land Use, Land Use Change and Forestry (LULUCF) Sector to be accounted for, subject to constraints, in efforts to reduce national GHG emissions (European Council, 2014). This means that carbon sequestration may provide a pivotal pathway to meeting national ambitions on emissions trajectories. When adopted, the framework will set emission reduction targets for individual MS, disaggregated by the Emissions Trading Sector (ETS) and the non-Emissions Trading Sector (non-ETS). No additional spatial disaggregation will be applied by EU policies. Given that the carbon content of most soils in Ireland is well in excess of 2\%, we chose the Climate and Energy Framework 2030, with its national targets for emissions reductions, as the main driver of the demand for carbon sequestration.

The demand for biodiversity is framed by multiple policies that include the Habitats Directive (EU, 1992), Birds Directive (EU, 2009), Water Framework Directive (EU, 2000), the

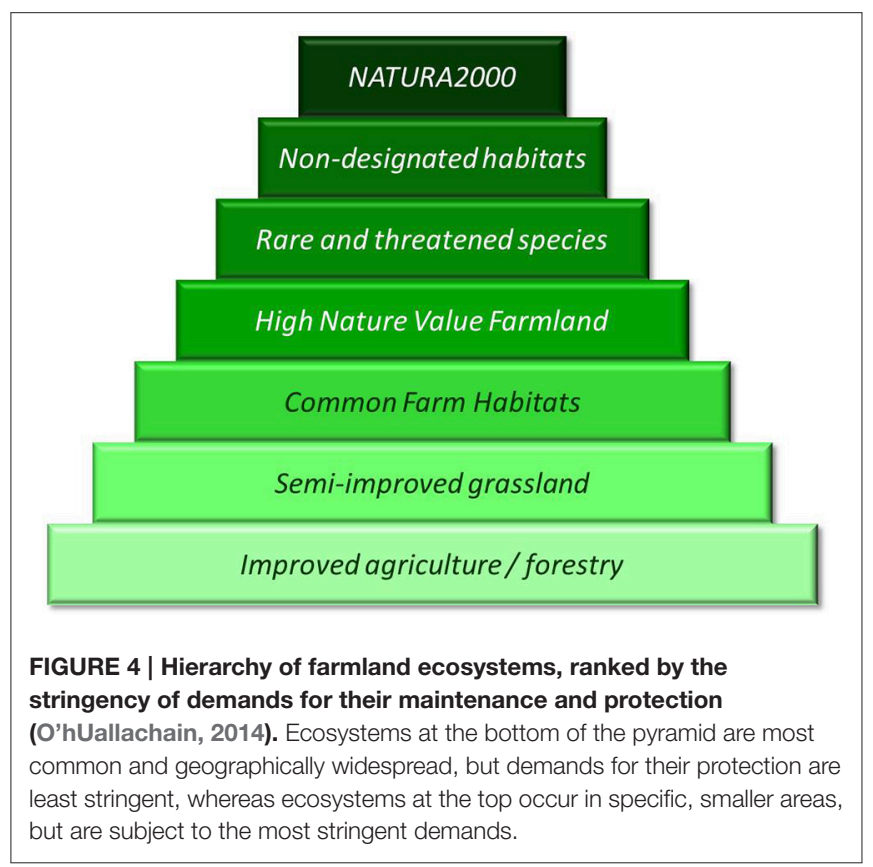

EU Biodiversity Strategy (EU, 2011), Greening Requirements (CAP Pillar 1) and agri-environment schemes (CAP Pillar 2). Previously, in a presentation to national policy makers of the Joint Oireachtas Committee on Agriculture, Food and the Marine, O'hUallachain (2014) ordered these into a "hierarchy of demands," ranging from the most stringent demands that apply to Natura 2000 sites to the least stringent demands that apply to improved grasslands outside protected areas (Figure 4). We adopted this hierarchy to frame the policy demand for biodiversity, using data from O'Sullivan et al. (2015), the National Parks and Wildlife Service (NPWS), the Land Parcel Identification System (LPIS) from the Department of Agriculture, Food and the Marine, and CORINE land cover data provided by the Environmental Protection Agency.

The demand for nutrient cycling is framed by two EU policies, namely the Nitrates Directive (EU, 1991) and the Sewage Sludge Directive (EU, 1986). These two Directives frame the demand 
for sustainable disposal and application of intensive animal enterprise (i.e., pig slurry and poultry manure) and sewage sludge, respectively. This has proven particularly challenging for pig slurry, which has a relatively low dry matter content and high water content, resulting in the need to transport large volumes of dilute material. Therefore, the sustainable disposal and application of pig slurry on land that has the capacity (biophysically and legally) to process the additional external nutrients, is primarily constrained by the costs of transport. In this context, we selected the area required for the sustainable disposal of slurry from the pig farms in the country as the relevant proxy-indicator for nutrient cycling, constraining the application rate to the maximum rate of $19 \mathrm{~kg}$ phosphorus $\mathrm{ha}^{-1}$ year ${ }^{-1}$. In addition, we added the area required to sustainably dispose of the volume of sewage sludge produced by towns and cities with a population in excess of 5000 inhabitants.

\section{Governance Tools for Functional Land Management}

To meet the second objective of the paper, we conducted a literature review to derive an inventory of governance instruments available to policy makers to manage the supply of soil functions at local and national scales to the demands for these functions from local to continental scales. These instruments were categorized along two axes, i.e., (1) the spatial scale at which each of the instruments applies and (2) the nature of implementation (market-driven, mandatory, voluntary).

\section{RESULTS}

\section{Supply of Soil Functions}

The five supply maps show a high degree of granularity in the supply of each of the soil functions (Figure 5). Whilst some regional patterns emerge, particularly for the provision of primary production, biodiversity, and nutrient cycling, the supply of soil functions is primarily defined by local soil and land use characteristics (inset in the carbon sequestration supply map).

\section{Demand for Soil Functions}

Contrastingly, there are marked differences in the spatial patterns of the demands for the five soil functions, as illustrated by the bottom row of maps in Figure 5, with spatial variation manifesting itself from small scale (primary productivity) to regional scale (nutrient cycling) and national scale (carbon sequestration).

In most regions, the supply of primary productivity exceeds demand, which suggests that sufficient capacity is available for the increased productivity projected in the Food Harvest 2020 Strategy. This supports the earlier conclusions by Schulte et al. (2014) who reported average national stocking rates of 1.2 LSU

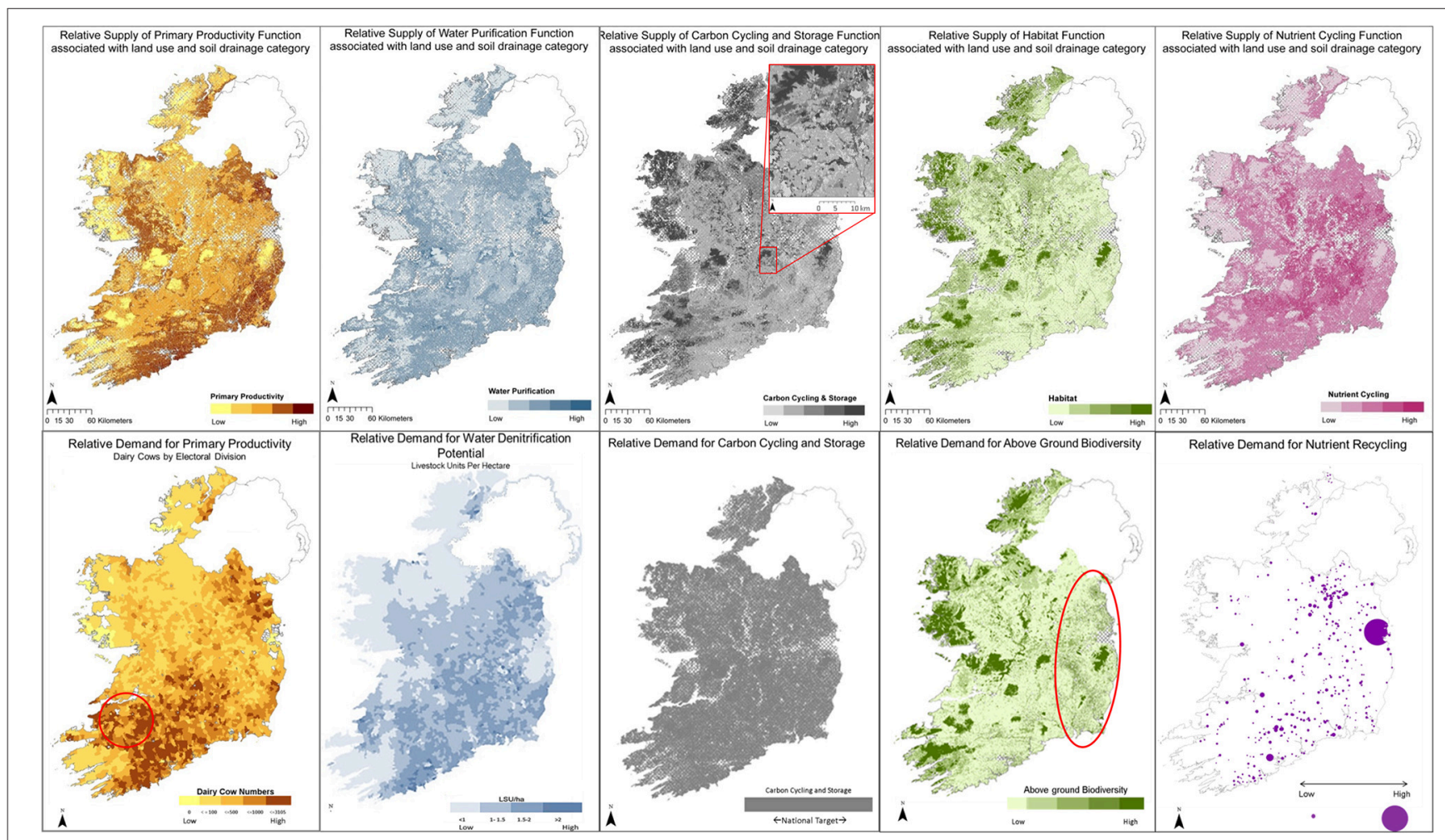

FIGURE 5 | Indicative maps of the normalized supply (top row) and demand (bottom row) for the five soil functions, from left to right: primary productivity, water purification, carbon sequestration, biodiversity, nutrient cycling. The red circle and oval indicate areas, discussed in the text, where the demand for primary productivity and biodiversity, respectively, may exceed the current supply of these two functions. 
per hectare, well below the carrying capacity of 1.5-1.8 LSU per hectare of most soils. A comparison of the supply and demand maps for primary productivity shows that the demand for increased productivity is highest in areas with a generous supply of this function (e.g., in the South-West, East, and North-East of Ireland), i.e., on soils that are traditionally classified as "good agricultural soils" (Lee and Diamond, 1972). However, there are exceptions, most notably in some South-Western regions (red circle), which are characterized by poorly-drained soils. In this region, a higher demand for primary productivity may only be met by an increased supply through the installation of artificial drainage systems, which moves the soil to a different drainage category; this will be considered in further detail in the Discussion.

The supply of denitrification, as a partial proxy for the function "water purification" is high in all regions, and adequately meets the demand that groundwater nitrate concentrations remain below $50 \mathrm{mg} \mathrm{l}^{-1}$. This is indeed reflected in the very high proportion of land (99\%) in Ireland that is in compliance with this demand (Byrne and Fanning, 2015).

Whilst the potential supply of the function "carbon sequestration" differs significantly between soil types, land use types, and management, the demand for this function applies to national scale only, as it is at this scale where GHG reduction targets will apply. Figure 5 illustrates this by assigning a uniform color to map the demand for carbon sequestration (note that waterbodies and urban areas show up in different shading). The EU 2030 Climate and Energy Framework has thus far only specified targets for GHG reductions at EU scale. Over time, this is expected to translate into national targets, but there are many difficulties associated with further downscaling these targets to regional or farm scale, including high transaction costs and concerns regarding the equitability of "carbon quota" in the context of diverse pedo-climatic environments (Teagasc, 2011).

A comparison of the supply and demand for the function "habitat for biodiversity" shows that one of the most stringent demands, i.e., the designation of Natura 2000 sites, has been met, although significant challenges remain in relation to the requirement to ensure favorable conservation status for these habitats (Schulte et al., 2014). Additional, more recent demands arising from the "Greening measures" of the CAP, include the requirement for Ecological Focus Areas (EFAs) to be implemented on arable land (red oval), which has traditionally been associated with a low supply of habitat.

The maps of the demand vs. supply of the soil function "nutrient cycling" show that the demand is low in comparison to the potential supply. This is a reflection of both the low pig population and human population in Ireland, compared to some of the other EU MS. Furthermore, the demand is strongly regional. The size of the circles represents the total area required to dispose of the organic nutrients. These circles represent an "ideal" scenario, where all of the land within the circle is suitable, and landowners are willing, to import the manure. In reality, finding suitable spreadlands can involve long travel distances.

\section{DISCUSSION}

\section{Maximizing or Optimizing Soil Functions?}

The concept of Functional Land Management neither seeks to maximize a unique soil function, nor all soil functions of all soils at the same time. Indeed, the latter has proven to be impossible, given that not only synergies, but also trade-offs exist between some of the soil functions (Power, 2010). For example, efforts to increase primary productivity on wet soils through the installation of subsurface drainage systems may reduce the capacity of a soil to perform the function of carbon sequestration (O’Sullivan et al., 2015). Instead, Functional Land Management constitutes a systems approach aimed at managing soils (and in a wider context: managing land) in such a way that the demands for soil functions are balanced and met everywhere, thus building on the recommendations by Bouma et al. (2012) and Kibblewhite et al. (2012). In light of the spatial variation of both the supply and demand for soil functions, this involves a process of "optimizing," rather than "maximizing" soil functions, subject to the balances of local demand and supply.

This subtle change in focus may help us to further develop the concept and definition of "Soil Quality." Almost two decades ago, the Soil Science Society of America (1997) defined Soil Quality as "The capacity of a specific kind of soil to function within natural or managed ecosystem boundaries, to sustain biological productivity, maintain environmental quality, and promote plant and animal health." Whilst this definition provides a utilitarian and hence pragmatic approach to soil quality that centers on "functionality," it is unbounded in that it does not provide a benchmark or scale for the assessment of soil quality. In light of the aforementioned potential for trade-offs and synergies between soil functions, there is merit in adding the clause "The capacity of a specific kind of soil to provide functions to meet demands, within...," which would add a benchmark for assessment. Additionally, it would introduce a degree of elasticity, since Soil Quality would no longer depend solely on soil properties and processes, but could also vary through a change in demand(s). Whilst this elasticity may be challenging from a scientific perspective, it provides a useful feedback mechanism to policy formation, specifically in the formulation of demands on soil functions. Put simply: it could help in assessing whether proposed demands are achievable or not.

\section{Pathways for Matching Supply to Demand}

When considering practical approaches to matching supply with demand, we can distinguish three contrasting pathways. In Figure 6 we illustrate these pathways with a case-study of a grass-based dairy farm located on a moderately-drained soil (green circle), where the farmer is planning to increasing primary productivity in response to the abolition of the EU milk quota. The first pathway to meet this "demand" for increased production involves optimizing selected soil functions at a local scale through soil management practices that change the dynamic soil properties, such as soil nutrient concentrations. Ideally, such good practices may augment a specific soil function without impacting on the others (the "larger white box" in Figure 6). For example, nutrient management planning based 


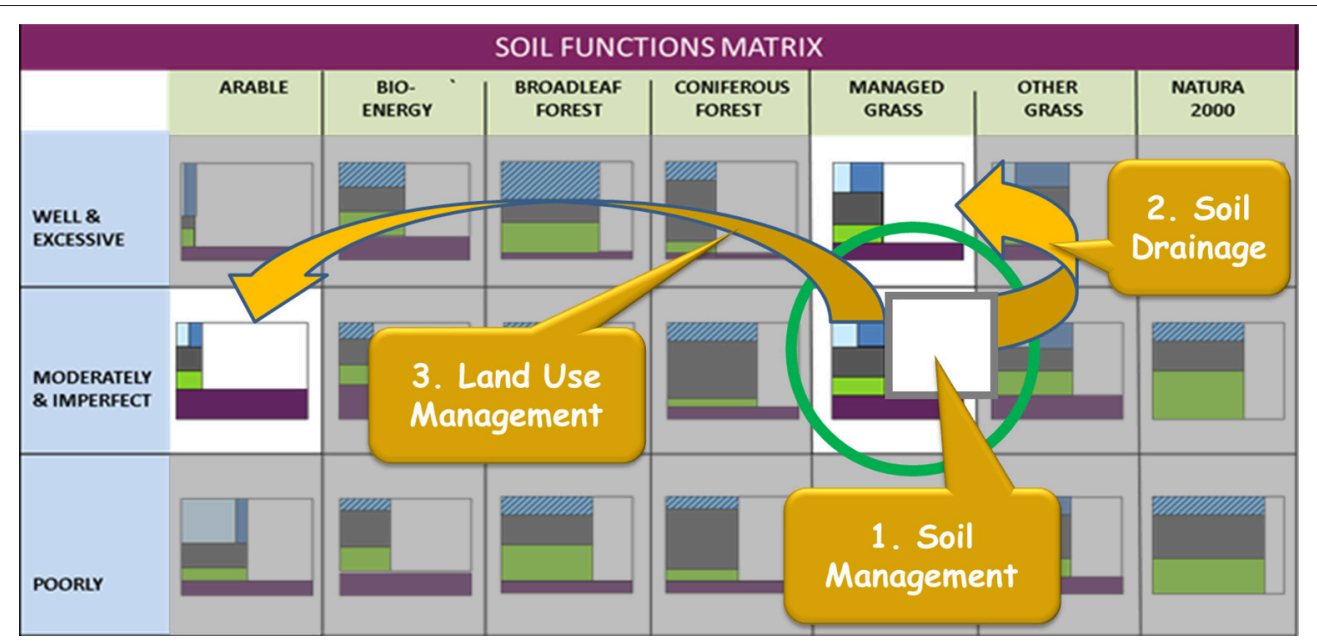

FIGURE 6 | Illustration of pathways for managing soil functions in Atlantic climates: (1) soil management, (2) soil drainage, and (3) land use management. The white boxes indicate primary production; blue, water purification and regulation; black, carbon storage and regulation; green, provision of a habitat for biodiversity; purple, cycling of nutrients.

on soil testing may increase the potential productivity of soils, without compromising other functions such as water purification (Murphy et al., 2015). Data from Ireland shows that as few as 10\% of agricultural soils have optimum $\mathrm{pH}$ levels, as well as optimum phosphorus and potassium concentrations, which demonstrates the potential offered by such simple and affordable measures (Wall et al., 2015). Other examples of this pathway include an increase in the use of animal manures in arable farming (at the expense of fertilizer usage), to augment the functions carbon sequestration and nutrient cycling (e.g., Lal, 2004). When managed correctly, without associated yield reductions or pressures on aquatic ecosystems, this would result in selective increases of the "black box" and "purple box," respectively, in Figure 6.

The second pathway involves interventions aimed at manipulating static soil properties in order to enhance one or more soil functions. In our case study of Atlantic climates (Figures 2, 6), this could involve the installation of subsurface drainage systems to change the drainage capacity and moisture dynamics of a soil, indicated by the second arrow in Figure 6; in other pedo-climatic zones, other types of interventions may be more appropriate. This pathway generally involves a local trade-off between soils functions. For example, in Atlantic climates, the installation of drainage systems typically reduces the prevalence of soil saturation and hence results in longer growing and grazing seasons (Tuohy et al., 2015). However, in some cases this increased productivity may come at the expense of the function water purification (e.g., Jahangir et al., 2012), as drainage systems increase the hydrological connectivity between pressure and aquatic receptors (Haygarth et al., 1998; Uusitalo et al., 2000). In addition, drainage of wet soils (which typically have high carbon contents) may lead to large carbon dioxide emissions, induced by oxygenation (Kechavarzi et al., 2010). O'Sullivan et al. (2015) showed that the cost:benefit ratio of this trade-off between the soil functions primary productivity and carbon sequestration differs significantly between soil types and meso-climatic conditions, and concluded that the aggregate merits of drainage interventions should be considered site-specific.

The third pathway refers to land use change (Arrow 3 in Figure 6), in this example a change from grassland to arable silage (e.g., forage maize). Similar to the second pathway, land use change typically results in a trade-off between functions. For example, the plowing and conversion of moderately-drained grassland to arable land may increase primary productivity, but this is likely to be at the expense of the capacity of the soil to perform the functions of water purification (Schulte et al., 2006) and regulation (Palmer and Smith, 2013), carbon sequestration (Lal, 2004) and habitat provision for biodiversity (Brussaard et al., 2007; Van Eekeren et al., 2008). It is important to consider that such trade-offs are not necessarily undesirable, provided that they do not irreversibly impede the potential of soil to perform other functions. For example, intensification of primary production may be desirable where the soils have "spare capacity" for water purification, and could be preferable to an alternative scenario of "expansion" of the agricultural production platform into surrounding areas with respect to the functions biodiversity and carbon sequestration, if these latter areas are of high nature value. Contrastingly, intensification through land use change may be undesirable on soils where the supply of the purification capacity cannot meet water quality requirements.

\section{The Role of Scale}

The spatial scale to which these demands apply will determine the extent to which the supply of soil functions can be offset between soils or regions. Soil differs from commodities such as air and water, in that most soils are owned and as a result managed at local scale. At the same time, we have seen that the demands for soil functions may range from local to continental scales, presenting landowners with a myriad of considerations. 
For example, the Nitrates Directive requires that groundwater nitrate concentrations are maintained below $50 \mathrm{mg} \mathrm{l}^{-1}$. This demand is ubiquitous and implies that the soil function of water purification cannot be "traded" between fields, farms or regions, where one location would compensate for the failure of another to provide clean water. Contrastingly, the Water Framework Directive has a regional focus, which allows for a degree of offsetting between land areas at a catchment scale. This means, on the one hand, that the impact of individual farms on the ecological status of surface waters may be "diluted" over a catchment. Conversely, this impact may be compounded by non-agricultural sources of nutrients, e.g., waste water treatment plants (Vrebos et al., 2015). Due to the directionality of river systems, the demand for the function "water purification" may be spatially separated from the demand. This may constrain options in relation to offsetting, especially in complex river systems.

At the other extreme, the demand for soils to sequester carbon applies ultimately to a global scale, as the atmospheric impacts are independent of the location of the sequestration. In practice, the demand for management of GHG applies at national scale. Either way, this larger scale allows for a degree of offsetting between soils or regions, where one soil may compensate for low rates of sequestration in other locations. This means that it may not be efficacious to translate national carbon sequestration targets into a requirement for every farmer to offset his/her emissions through land management. Instead, it may be more prudent to focus the delivery of this soil function on soils less suitable for the primary productivity function, e.g., by incentivizing farm forestry on these latter soils.

The same principles of offsetting apply, to some extent, to primary productivity, facilitated by the emergence of a global food system, although cognizance must be paid to the multiple advantages of regional supply management (e.g., Sonnino, 2013), which have been further highlighted by geopolitical developments in recent times.

The demands for the remaining two soil functions, biodiversity and nutrient cycling, apply at intermediate scales. The demand and supply dynamics of nutrient cycling are primarily governed by transport considerations (Fealy and Schröder, 2008), which restricts the options to match demand and supply at the regional scale. Demands to designate and protect biodiversity cut across multiple scales, as these pertain to the protection of individual rare species (local scale), entire habitats (regional scale), and the protection of species throughout their natural range (national scale) (Noss, 1990).

\section{Incentivization and Implementation}

The need for coherent management of soil functions across scales, from local to national and continental scale, does not equate to a requirement for top-down "zoning" of land for individual functions: the granularity of the supply of soil functions emerging from Figure 5 demonstrates that this may be unachievable in any case. Instead, individual soil functions may be incentivized by a range of instruments that have a long history within the framework of the EU CAP. These include mandatory incentives such as the cross-compliance and greening requirements of CAP Pillar 1, as well as voluntary incentives such as agri-environment schemes and the new Areas of Natural Constraints (ANC) of CAP Pillar 2. In Figure 7, we have categorized these instruments into market driven incentives, mandatory policies, and voluntary schemes, alongside the policy objectives, and have identified their corresponding spatial scale of application.

Policies at national scale focus on the management of land use. Examples include the mandatory requirement for MS to designate NATURA 2000 sites (Habitats and Birds Directives) and High Status Waterbodies (Water Framework Directive). Joint implementation of these two requirements allows for synergy and a seamless approach. For primary productivity, the main instrument to regulate demand is the market, specifically following the decoupling of payments from production levels, and the recent abolition of EU milk quota. At the same time, the Pillar 2 payments for ANC are an example of a voluntary scheme to compensate farmers for reduced capacity of soils to deliver primary productivity.

We could identify few mandatory policy instruments that apply consistently at regional scale across the EU, with the notable exception of the River Basin District Management Plans, which are the main instrument for managing water catchment areas as part of the Water Framework Directive. However, at national scale, other environmental policies are also governed and implemented at a regional to local scale, specifically in decentralized MS. For example, in federate Belgium, agricultural policies and the implementation of the WFD, Urban Waste Water Directive and Habitat Directive are all governed at regional scale (Flanders, Walloon, Brussels). Similarly, voluntary policy instruments may be implemented at regional scale. One example are the agri-environment schemes of the Po Valley, which is characterized by the most intensive and productive agricultural systems of Italy, which typically deliver a low "supply" of the function "Habitat for biodiversity." Apart from river networks and Natura 2000 sites, permanent grasslands represent the most relevant additional hotspots of biodiversity (Assolari et al., 2004), and higher soil carbon stocks (Gardi et al., 2002). The historic extent of this land use type has been significantly reduced over the last 50 years. Several regions have now tailored the agri-environment schemes financed by CAP, in order to provide economic incentives for the conservation of permanent grasslands.

Finally, at the local scale, a continuum of incentives are focussed on the augmentation of selective soil functions, ranging from the mandatory requirement to maintain soil carbon contents in excess of $2 \%$ in order to maintain soil quality, greening requirements, nitrates regulations and mandatory Environmental Impact Assessment, to voluntary agrienvironment schemes and quality assurance schemes aimed at enhancing local soil management practices to ensure delivery of the water purification and habitat functions (e.g., https://www. glanbiaingredientsireland.com/sustainability/farm).

A comparison of the policy objectives (left-hand side of Figure 7) and policy instruments (right-hand side of Figure 7) shows that, in principle, policy makers have a wide menu of instruments at their disposal to incentivize soil and land management to meet policy objectives. In other words: the 


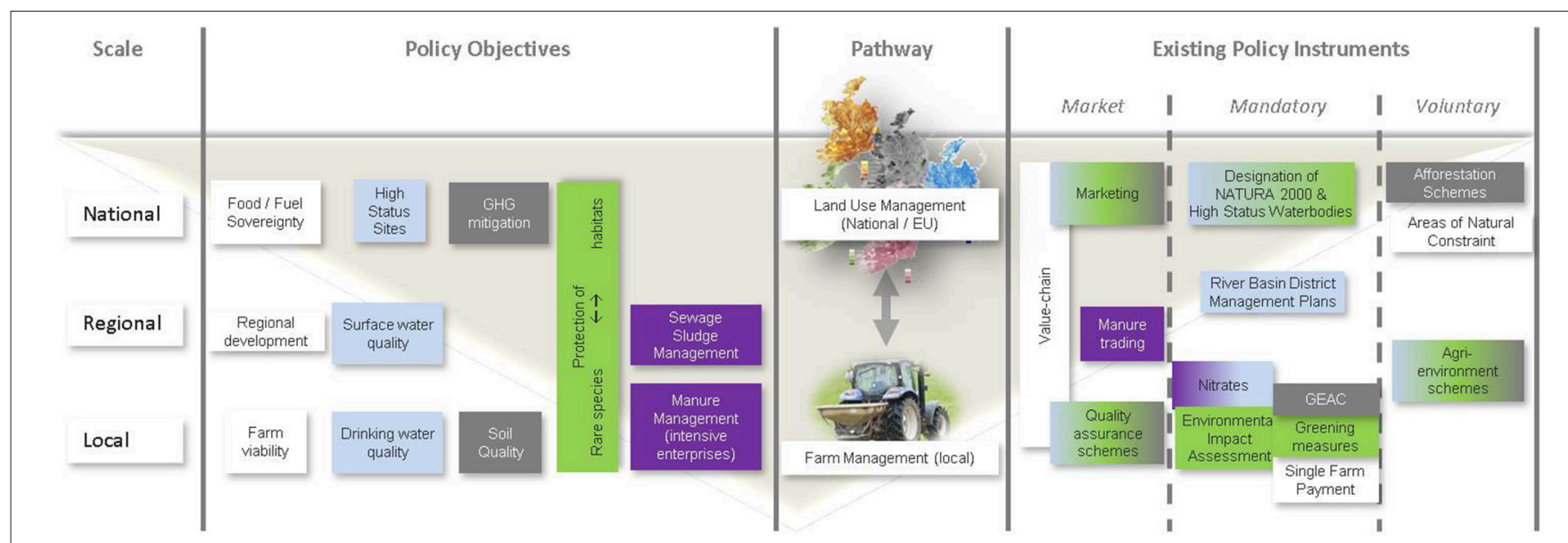

FIGURE 7 | Inventory of policy objectives and policy instruments of relevance to the management of soil functions. The color coding refers to the soil functions of relevance to each of the objectives and instruments: white, primary production; blue, water purification and regulation; black, carbon storage and regulation; green, provision of a habitat for biodiversity; purple, cycling of nutrients.

individual policy tools for Functional Land Management are available for the management of soil functions at the appropriate scale. Some of the policy tools are "joined up" in addressing multiple soil functions: for example, through the mechanism of cross-compliance, the Good Agri-Environmental Condition (GAEC) requirements and the Greening requirements are tied into eligibility for the full Single Farm Payment (SFP) scheme. However, there are an equal number of relevant instruments that operate in isolation of each other. For example, soils that are less suitable to provide food are currently being identified as part of the re-delineation of ANC. This offers opportunities to target afforestation incentives to such areas, to negate competition for land between the production of food and fiber. Another example is the Environmental Impact Assessment, a mandatory requirement for large-scale land-management interventions, such as the installation of drainage systems. This assessment only applies to the soil function of habitat provision. In light of the aforementioned potential impact of soil drainage on the carbon sequestration function, there may be room for a more holistic approach that addresses multiple soil functions.

Secondly, most of these policy instruments were developed in response to a multitude of diverging policies that originate from more than one body of the European Union or its MS. As a result, these instruments are often developed and administered by multiple actors that include multiple ministries and local authorities, and in the case of quality assurance schemes, also commercial entities such as primary processors and retail chains. Anecdotal evidence suggests that this has imposed complex and at times confusing requirements for record keeping on landowners. Whilst this may be considered necessary from a regulatory perspective, this complexity carries the risk that landowners will view "sustainable land management" from a perspective of compliance, rather than an opportunity "to make the most of our land," even where negative financial trade-offs are compensated for by support mechanisms. In any case, financial benefits, either short-term or long-term, may not always be self-evident to farmers. For example, the benefits of enhanced carbon sequestration as a climate change mitigation measure, accrue at societal level, rather than at farm scale (Gutzler et al., 2015).

Finally, many if not most of the instruments do not account for differences between soils in their capacity to supply soil functions. This implies that these instruments are implicitly based on the "old" concept that seeks to maximize either one, or all soil functions simultaneously. If we accept that the availability of land, be it at local, national or continental scale, is a limiting factor in meeting the demands for all major soil functions simultaneously, then we need policy instruments that aim to optimize, rather than maximize, the supply of soil functions, which means that differences between soil types need to be accounted for. To date, this has been impeded mainly by the unavailability or incompleteness of soils data at national scales in many EU MS, compounded by inconsistencies between datasets. However, many of these challenges are currently being addressed in countries with poor soil information, as part of the ongoing new delineation of ANCs across the EU (Eliasson et al., 2010), which requires the consistent mapping of soil properties within and between MS (Van Orshoven et al., 2012). Upon completion, this could also be used to customize and fine-tune the other policy instruments to take account of differences between soils.

\section{Application at European Scale}

In this paper, we used Ireland as a case-study to illustrate the variety of scales to which the demand for soil functions may apply, and how an integrated approach to policy formation, across spatial scales, is required to optimize the supply of soil functions to meet societal demands for food, clean water, climate change mitigation, biodiversity and the sustainable management of manure and sewage. At this point, it is prudent for us to emphasize that we developed this case-study merely for the purpose of illustrating our framework. Whilst the apportioning of the supply of soil functions in Figure $\mathbf{2}$ is based on an extensive 
literature review and conceptual modeling (Coyle et al., 2015), this is not yet underpinned by direct empirical data. Instead, this is the subject of the current SQUARE (Soil QUality: Assessment and REsearch) project, in which we are measuring the supply of the five soil functions at more than 40 sites across Ireland, with a view to validating the matrix presented in Figure 2 (see http:// www.teagasc.ie/soil/square/).

Similarly, the main purpose of the maps in Figure 5 is to illustrate the high level of small-scale granularity in the supply of soil functions, and the diverging spatial scales at which each of the demands for soil functions applies. While these maps may be used to aid the identification and interpretation of large-scale geographical patterns, they are not appropriate for aiding management decisions at local (i.e., farm) scale. These maps were derived from the 1:250,000 third generation soil map of Ireland. At that scale, polygons represent associations of soil types that occur together in a landscape but may exhibit diverging properties. Therefore, local management of soils requires knowledge of local soil types, which can only be derived through direct observations.

In addition, while we are confident that our five soil functions comprehensively cover the main demands on land in Europe, our choice of proxy-indicators provide only a partial representation of these soil functions. For example, in this paper we chose the dentrification capacity of soil as a partial proxy-indicator for the function water purification and regulation, for illustrative purposes only. A full analysis would have to include additional proxy-indicators, for example to quantify the capacity of soils to adsorb phosphorus or agro-chemicals, or the capacity of soils to regulate water quantities and prevent droughts and/or floods. Indeed, other MS may need different or additional proxyindicators in order to adequately frame both the supply and demand for soil functions. In our example, we used soil drainage as the dominant soil property that, together with land use, determines the supply of soil functions in Atlantic climates. In other biogeographical zones in Europe, the supply may depend primarily on other soil properties (e.g., $\mathrm{pH}$, texture) or other land use types that we did not include in our case-study (e.g., viticulture). The identification of common criteria (soil properties) for the delineation of ANCs (Van Orshoven et al., 2012) may prove a useful step in identifying the most appropriate soil properties for each biogeographical zone.

The demand for soil functions may equally differ between localities, regions and countries. For example, there are large differences in nitrogen surplus across Europe (Leip et al., 2011a) and regions with larger nutrient surpluses will see a higher demand on soils for water purification (e.g., Uwizeye et al., accepted). Areas with large urban conglomerations or intensive farm enterprises (e.g., pig or poultry industry) may put a larger demand on soils for nutrient cycling, for example in Denmark (Dalgaard et al., 2011) and in the Flanders region of Belgium (Van der Straeten et al., 2010). Contrastingly, countries with proportionally high agricultural gaseous emissions may emphasize the demand on soils to sequester carbon (e.g., Leip et al., 2011b; Department of Agriculture, Food and the Marine, 2015; Embassy of France, 2015.

This upscaling of the concept of Functional Land Management to EU scale is the primary objective of the new Horizon 2020 project LANDMARK (LAND Management: Assessment, Research, Knowledge base), a consortium of 22 partner institutes from 14 EU countries plus Switzerland, China and Brazil. For full details follow @LANDMARK2020 on Twitter.

\section{CONCLUSIONS}

Soils provide multiple ecosystem services for society, which can be grouped into five "soil functions": primary productivity, water purification and regulation, carbon sequestration, providing a home for biodiversity, and recycling of nutrient. While all soils can perform all functions at the same time, the relative suite of functions that can be supplied by a soil depends primarily on land use and soil properties. Given the fine-grained spatial variability of both land use and soil properties, the supply of the five soil functions may vary from field to field.

Most of the societal demands for soil functions emanate from European policies relating to agriculture and the rural environment. These demands may apply to very different spatial scales: for some functions, such as the provision of clean groundwater, the demand applies at the field scale, while for other functions, such as mitigation of GHG emissions through carbon-sequestration, the demand applies at national or even continental scale. This wide range of scales of application has profound implications for the management for soil functions, specifically with respect to the "tradability" of the supply of soil functions between regions: some functions must be managed (e.g., by individual farmers) at a local scale, whereas other may be "traded" between regions.

The concept of Functional Land Management seeks to optimize, rather than maximize, the supply of soil functions to meet societal demands, without resorting to "top-down zoning" of land management. Across the EU, we identified 14 types of governance instruments for land management at local, regional and national scales, that could in principle be used to facilitate Functional Land Management. Most of these address the management of soil functions indirectly, and do not account for differences between soils in their capacity to supply soil functions, due to a historic knowledge deficit of European soil resources at a relevant scale. The current process of re-delineation of ANC may provide a harmonized platform to rectify this and customize policy instruments for these differences. Such customization could negate the need to develop new government instruments, and could instead aid the alignment of existing instruments with a view to developing a coherent approach to land management.

\section{ACKNOWLEDGMENTS}

This study was conducted as part of the LANDMARK (LAND Management: Assessment, Research, Knowledge Base) project. LANDMARK has received funding from the European Union's Horizon 2020 research and innovation programme under grant agreement No 635201. The SQUARE (Soil QUality Assessment and REsearch) project, mentioned in the text, is funded by the Research Stimulus Fund of the Department of Agriculture, Food and the Marine of the Government of Ireland. 


\section{REFERENCES}

Alexandratos, N., and Bruinsma, J. (2012). World Agriculture Towards 2030/2050. The 2012 Revision. Rome: FAO. Available online at: http://www.fao.org/docrep/ 016/ap106e/ap106e.pdf

Assolari, S., Peressotti, A., Tomat, E., and Zerbi, G. (2004). "Permanent meadows in natural reserves of Friuli Venezia Giulia: a study on their biodiversity and ecological characteristics. Global Challenges of Parks and Protected Area Management," in Proceedings of the 9th ISSRM, October 10-13, 2002 (La Maddalena), 33.

Bouma, J., Broll, G., Crane, T. A., Dewitte, O., Gardi, C., Schulte, R. P. O., et al. (2012). Soil information in support of policy making and awareness raising. Curr. Opin. Sustain. 4, 552-558. doi: 10.1016/j.cosust.2012. 07.001

Bruinsma, J. (2009). The Resource Outlook to 2050: By How Much Do Land, Water and Crop Yields Need to Increase by 2050? FAO Expert Meeting on How to Feed the World in 2050. Rome. Available online at: ftp://ftp.fao.org/agl/aglw/docs/ ResourceOutlookto2050.pdf

Brussaard, L., De Ruiter, P. C., and Brown, G. G. (2007). Soil biodiversity for agricultural sustainability. Agric. Ecosyst. Environ. 121, 233-244. doi: 10.1016/j.agee.2006.12.013

Byrne, C., and Fanning, A. (eds.). (2015). Water Quality in Ireland 2010-2012. Wexford: Environmental Protection Agency. Available online at: http://www. epa.ie/pubs/reports/water/waterqua/wqr20102012/WaterQualityReport.pdf

COPA-COGECA (2008). Farming Sector Supports the Thematic Strategy on Soil Protection but Rejects Bureaucratic New Directive. Brussels: Press release, COPA-COGECA. Available online at: http://www.copa-cogeca.be/Download. ashx?ID=423402\&fmt $=$ pdf

Cotula, L., Vermeulen, S., Leonard, R., and Keeley, J. (2009). Land Grab or Development Opportunity? Agricultural Investment and International Land Deals in Africa. Rome: FAO. Available online at: ftp://ftp.fao.org/docrep/fao/ 011/ak241e/ak241e.pdf

Coyle, C., Creamer, R. E., Schulte, R. P. O, O’Sullivan, L., and Jordan, P. (2015). A Functional Land Management conceptual framework under soil drainage and land use scenarios. Environ. Sci. Policy 56, 39-48. doi: 10.1016/j.envsci.2015.10.012

Creamer, R. E., Simo, I., Reidy, B., Carvalho, J., Fealy, R., Hallett, S., et al. (2014). Irish Soil Information System - Synthesis Report (2007-S-CD-1-S1). Wexford: Teagasc. Available online at: http://gis.teagasc.ie/soils/downloads/EPA_RR130_PRINT.pdf

Dalgaard, T., Hutchings, N., Dragosits, U., Olesen, J. E., Kjeldsen, C., Drouet, J. L., et al. (2011). Effects of farm heterogeneity and methods for upscaling on modelled nitrogen losses in agricultural landscapes. Environ. Pollut. 159, 3183-3192. doi: 10.1016/j.envpol.2011.02.043

Deloitte (2014). "Study supporting potential land and soil targets under the 2015 Land Communication," in Report Prepared for the European Commission, DG Environment in Collaboration with AMEC, IVM and WU. Available online at: http://bookshop.europa.eu/en/study-supporting-potential-land-targets-underthe-2014-land-communication-pbKH0414979/downloads/KH-04-14-979-ENN/KH0414979ENN_002.pdf?FileName $=$ KH0414979ENN_002.pdf\&SKU=KH 0414979ENN_PDF\&CatalogueNumber=KH-04-14-979-EN-N

Department of Agriculture, Food and the Marine (2009). Maintenance of Soil Organic Matter. Available online at: https://www.agriculture.gov.ie/media/ migration/farmingschemesandpayments/crosscompliance/soilorganicmatter/ Soil\%20organic\%20matter\%20guidelines.pdf

Department of Agriculture, Food and the Marine (2010). Food Harvest 2020: A Vision for Agri-Food and Fisheries. Available online at: https://www. agriculture.gov.ie/media/migration/agri-foodindustry/foodharvest2020/ 2020FoodHarvestEng240810.pdf

Department of Agriculture, Food and the Marine (2015). A Discussion Document on the Potential for Greenhouse Gas (GHG) Mitigation within the Agriculture and Forestry Sector. Available online at: http://www.agriculture. gov.ie/media/migration/ruralenvironment/climatechange/ghgmitigation/ AgriSectorMitigationPlanPublicConsult120215.pdf

Eliasson, Å., Jones, R. J. A., Nachtergaele, F., Rossiter, D. G., Terres, J.-M., Van Orshoven, J., et al. (2010). Common criteria for the redefinition of Intermediate Less Favoured Areas in the European Union. Environ. Sci. Policy 13, 766-777. doi: 10.1016/j.envsci.2010.08.003
Embassy of France (2015). 4 for 1000: A New Program for Carbon Sequestration in Agriculture. Embassy of France (United States). Available online at: http:// frenchfoodintheus.org/2285

EU (1986). Council Directive of 12 June 1986 on the Protection of the Environment, and in Particular of the Soil, When Sewage Sludge is Used In Agriculture (86/278/EEC). European Union. Available online at: http://eur-lex.europa.eu/ LexUriServ/LexUriServ.do?uri=OJ:L:1986:181:0006:0012:EN:PDF

EU (1991). Council Directive of 12 December 1991 Concerning the Protection of Waters Against Pollution Caused by Nitrates from Agricultural Sources (91/676/EEC). European Union. Available online at: http://eur-lex.europa.eu/ LexUriServ/LexUriServ.do?uri=OJ:L:1991:375:0001:0008:EN:PDF

EU (1992). Council Directive 92/43/EEC of 21 May 1992 on the Conservation of Natural Habitats and of Wild Fauna and Flora. European Union. Available online at: http://eur-lex.europa.eu/LexUriServ/LexUriServ.do?uri=CONSLEG: 1992L0043:20070101:EN:PDF

EU (2000). Directive 2000/60/EC of the European Parliament and of the Council of 23 October 2000 Establishing a Framework for Community Action in the Field of Water Policy. European Union. Available online at: http://eur-lex.europa.eu/resource.html?uri=cellar:5c835afb-2ec6-4577-bdf8-75 6d3d694eeb.0004.02/DOC_1\&format=PDF

EU (2009). Directive 2009/147/EC of the European Parliament and of the Council of 30 November 2009 on the Conservation of Wild Birds (Codified Version). European Union. Available online at: http://eur-lex.europa.eu/LexUriServ/ LexUriServ.do?uri=OJ:L:2010:020:0007:0025:EN:PDF

EU (2011). Resolution 2011/2307(INI): Our Life Insurance, our Natural Capital: An EU Biodiversity Strategy to 2020. European Union. Available online at: http://ec.europa.eu/environment/nature/biodiversity/comm2006/pdf/EP_resol ution_april2012.pdf

European Commission (2006a). Communication from the Commission to the Council, the European Parliament, the European Economic and Social Committee and the Committee of the Regions - Thematic Strategy for Soil Protection (COM 2006. 231). Brussels: Commission of the European Communities.

European Commission (2014) "REFIT - Fit for growth": Examples How EU Law is Becoming Lighter, Simpler and Cheaper. Brussels: Commission of the European Communities. Available online at: http://europa.eu/rapid/press-release_MEMO-13-833_en.htm

European Commission (2006b). Proposal of a Directive of the European Parliament and of the Council 2006 Establishing a Framework for the Protection of Soil and Amending Directive 2004/35/EC. Brussels: Commission of the European Communities.

European Council (2014). European Council (23 and 24 October 2014) Conclusions on 2030 Climate and Energy Policy Framework. Available online at: http://www.consilium.europa.eu/uedocs/cms_data/docs/pressdata/en/ec/1453 56.pdf

Evans, E. (2009). The Feeding of the Nine Billion: Global Food Security for the 21st Century. London: Chatham House Report. Available online at: http://www.chathamhouse.org/sites/default/files/public/Research/Energy, $\% 20$ Environment\%20and\%20Development/r0109food.pdf

FAO (2015). A Review of Indicators and Methods to Assess Biodiversity - Application to Livestock Production at Global Scale. Livestock Environmental Assessment and Performance Partnership. Rome: Food and Agricultural Organisation of the United Nations. Available online at: http://www.fao.org/3/a-av151e.pdf

FAOSTAT (2013). Food and Agricultural Organisation of the United Nations. Available online at: http://faostat.fao.org/

Fealy, R., and Schröder, J. (2008). "Assessment of manure transport distances and their impact on economic and energy costs," in Proceedings of the International Fertiliser Society, Vol. 642 (Colchester: International Fertiliser Society).

Gardi, C., Tomaselli, M., Parisi, V., Petraglia, A., and Santini, C. (2002). Soil quality indicators and biodiversity in northern Italian permanent grasslands. Eur. J. Soil Biol. 38, 103-110. doi: 10.1016/S1164-5563(01)01111-6

Gerland, P., Raftery, A. E., Ševčíková, H., Li, N., Gul, D., Spoorenberg, T., et al. (2014). World population stabilization unlikely this century. Science 346, 234-237. doi: 10.1126/science. 1257469

Ghaley, B. B., Sandhu, H. S., and Porter, J. R. (2015). Relationship between $\mathrm{C}: \mathrm{N} / \mathrm{C}: \mathrm{O}$ stoichiometry and ecosystem services in managed production systems. PLoS ONE. 10:e0123869. doi: 10.1371/journal.pone. 0123869 
Government of Ireland (2009). Statutory Instrument No. 101 of 2009: European Communities (Good Agricultural Practice for Protection of Waters) Regulations 2009. Available online at: https://www.agriculture.gov.ie/media/migration/ ruralenvironment/environment/nitrates/SI\%20101-2009.pdf

Gutzler, C., Donnellan, T., Murphy, P., O’Mara, F., Richards, K., and Schulte, R. P. O. (2015). Teagasc Submission to the European Commission Consultation on "Addressing greenhouse gas emissions from agriculture and LULUCF in the context of the $2030 \mathrm{EU}$ climate and energy framework." Available online at: http://ec.europa.eu/clima/consultations/articles/0026_en.htm

Haygarth, P. M., Hepworth, L., and Jarvis, S. C (1998). Forms of phosphorus transfer in hydrological pathways from soil under grazed grassland. Eur. J. Soil Sci. 49, 65-72. doi: 10.1046/j.1365-2389.1998.00131.x

Jahangir, M. M. R., Johnston, P., Khalil, M. I., Hennessy, D., Humphreys, J., Fenton, O., et al. (2012). Groundwater: a pathway for terrestrial C and $\mathrm{N}$ losses and indirect greenhouse gas emissions. Agric. Ecosyst. Environ. 159, 40-48. doi: 10.1016/j.agee.2012.06.015

Kechavarzi, C., Dawson, Q., Bartlett, M., and Leeds-Harrison, P. B. (2010). The role of soil moisture, temperature and nutrient amendment on $\mathrm{CO}_{2}$ efflux from agricultural peat soil microcosms. Geoderma 154, 203-210. doi: 10.1016/j.geoderma.2009.02.018

Keesstra, S., Mol, G., Zaal, A., Wallinga, J., and Jansen, B. (eds.). (2015). "Soil science in a changing world," in Wageningen Soil Conference 2015 (Wageningen).

Kibblewhite, M. G., Miko, L., and Montanarella, L. (2012). Legal frameworks for soil protection: current development and technical information requirements. Curr. Opin. Environ. Sustain. 4, 573-577. doi: 10.1016/j.cosust.2012.08.001

Lal, R. (2004). Soil carbon sequestration to mitigate climate change. Geoderma 123, 1-22. doi: 10.1016/j.geoderma.2004.01.032

Lee, J., and Diamond, J. (1972). The Potential of Irish Land for Livestock Production. Dublin: An Foras Taluntais.

Leip, A., Britz, W., Weiss, F., and de Vries, W. (2011a). Farm, land, and soil nitrogen budgets for agriculture in Europe calculated with CAPRI. Environ. Pollut. 159, 3243-3253. doi: 10.1016/j.envpol.2011.01.040

Leip, A., Busto, M., and Winiwarter, W. (2011b). Developing spatially stratified $\mathrm{N}_{2} \mathrm{O}$ emission factors for Europe. Environ. Pollut. 159, 3223-3232. doi: 10.1016/j.envpol.2010.11.024

Maes, J., Egoh, B., Willemen, L., Liquete, C., Vihervaara, P., Schagner, J. P., et al. (2012). Mapping ecosystem services for policy support and decision making in the European Union. Ecosyst. Serv. 1, 31-39. doi: 10.1016/j.ecoser.2012. 06.004

Marchal, V., Dellink, R., Van Vuuren, D., Clapp, C., Château, J., Magné, B., et al. (2012). "Climate change" in OECD Environmental Outlook to 2050: The Consequences of Inaction. Paris: OECD Publishing.

Metzger, M. J., Bunce, R. G. H., Jongman, R. H. G., Mücher, C. A., and Watkins, J. W. (2005). A climatic stratification of the environment of Europe. Glob. Ecol. Biogeogr. 14, 549-563. doi: 10.1111/j.1466-822X.2005.00190.x

Montanarella, L., and Vargas, R. (2012). Global governance of soil resources as a necessary condition for sustainable development. Curr. Opin. Environ. Sustain. 4, 559-564. doi: 10.1016/j.cosust.2012.06.007

Murphy, P. N. C., Mellander, P-E., Melland, A. R., Buckley, C., Shore, M., Shortle, G., et al. (2015). Variable response to phosphorus mitigation measures across the nutrient transfer continuum in a dairy grassland catchment. Agric. Ecosyst. Environ. 207, 192-202. doi: 10.1016/j.agee.2015.04.008

Nachtergaele, F. O., Petri, M., Biancalani, R., Lynden, G., Van Velthuizen, H., and Van Bloise, M. (2011). Global Land Degradation Information System (GLADIS). Version 1.0 An Information Database for Land Degradation Assessment at Global Level. LADA Technical Report no. 17. Rome: FAO.

Noss, R. F. (1990). Indicators for monitoring biodiversity - a hierarchical approach. Conserv. Biol. 4, 355-364. doi: 10.1111/j.1523-1739.1990.tb00309.x

O'hUallachain, D. (2014). Demands on Land Use in Ireland: 3. Agro-Ecology. Presentation to the Joint Oireachtas Committee on Agriculture, Food and the Marine. Available online at: https://www.kildarestreet.com/committees/? id $=2014-04-08$ a.7

O’Sullivan, L., Creamer, R. E., Fealy, R., Lanigan, G., Simo, I., Fenton, O., et al. (2015). Functional Land Management for managing soil functions: a case-study of the trade-off between primary productivity and carbon storage in response to the intervention of drainage systems in Ireland. Land Use Policy 47, 42-54. doi: 10.1016/j.landusepol.2015.03.007
Palmer, R. C., and Smith, R. P. (2013). Soil structural degradation in SW England and its impact on surface-water runoff generation. Soil Use Manage. 29, 567-575. doi: 10.1111/sum.12068

Power, A. G. (2010). Ecosystem services and agriculture: tradeoffs and synergies. Philos. Trans. R Soc. 365, 2959-2971. doi: 10.1098/rstb.2010.0143

Robinson, R. A., and Sutherland, W. J. (2002). Post-war changes in arable farming and biodiversity in Great Britain. J. Appl. Ecol. 39, 157-176. doi: 10.1046/j.13652664.2002.00695.x

Sauer, T. J., Norman, J. M., and Sivakumar, M. V. K. (2011). Sustaining Soil Productivity in Response to Global Climate Change. Science, Policy and Ethics. Ames, IA: Wiley-Blackwell.

Schulte, R. P. O., Creamer, R. E., Simo, I., and Holden, N. M. (2015). A note on the Hybrid Soil Moisture Deficit Model v2.0. Ir. J. Agric. Food Res. 54, 126-131. doi: 10.1515/ijafr-2015-0014 IJAFR

Schulte, R. P. O., Richards, K., Daly, K., Kurz, I., McDonald, E. J., and Holden, N. M. (2006). Agriculture, meteorology and water quality in Ireland: a regional evaluation of pressures and pathways of nutrient loss to water. Biol. Environ. 106B, 117-134. doi: 10.3318/bioe.2006.106.2.117

Schulte, R. P. O., Creamer, R. E., Donnellan, T., Farrelly, N., Fealy, R., O’Donoghue, C., et al. (2014). Functional land management: a framework for managing soil-based ecosystem services for the sustainable intensification of agriculture. Environ. Sci. Policy 38, 45-58. doi: 10.1016/j.envsci.2013.10.002

Schulte, R. P. O., Fealy, R., Creamer, R. E., Towers, W., Harty, T., and Jones, R. J. A. (2012). A review of the role of excess soil moisture conditions in constraining farm practices under Atlantic conditions. Soil Use Manage. 28, 580-589. doi: 10.1111/j.1475-2743.2012.00437.x

Smith, P., Martino, D., Cai, Z., Gwary, D., Janzen, H., Kumar, P., et al. (2007). "Agriculture," in Climate Change 2007: Mitigation. Contribution of Working Group III to the Fourth Assessment Report of the Intergovernmental Panel on Climate Change, eds B. Metz, O. R. Davidson, P. R. Bosch, R. Dave, and L. A. Meyer (Cambridge, UK; New York, NY: Cambridge University Press). Available online at: http://www.ipcc.ch/pdf/assessment-report/ar4/wg3/ ar4-wg3-chapter8.pdf

Soil Science Society of America (1997). Glossary of Soil Science Terms. Madison, WI: Soil Science Society of America.

Sonnino, R. (2013). Local foodscapes: place and power in the agri-food system. Acta Agric. Scand. B Soil Plant Sci. 63, 2-7. doi: 10.1080/09064710.2013.800130

Spink, J., Hackett, R., Forristal, D., and Creamer, R. (2010). Soil Organic Carbon: A review of 'critical' Levels and Practices to Increase Levels in Tillage Land in Ireland. Carlow: Teagasc. Available online at: http://www.teagasc.ie/ publications/2010/982/SoilOrganicCarbon.pdf

Teagasc (2011). Carbon Audits for Irish Agriculture. Carlow: Teagasc. Available online at: http://www.teagasc.ie/publications/view_publication.aspx?Publicatio $\mathrm{nID}=1063$

Tscharntke, T., Klein, A. M., Kruess, A., Steffan-Dewenter, I., and Thies, C. (2005). Landscape perspectives on agricultural intensification and biodiversity - ecosystem service management. Ecol. Lett. 8, 857-874. doi: 10.1111/j.14610248.2005.00782.x

Tuohy, P., Fenton, O., and Holden, N. M. (2015). The effects of treading by two breeds of dairy cow with different live weights on soil physical properties, poaching damage and herbage production on a poorly drained clay-loam soil. J. Agric. Sci. 153, 1424-1436. doi: 10.1017/S0021859614001099

Uusitalo, R., Turtolaa, E., Kauppilab, T., and Liljaa, T. (2000). Particulate phosphorus and sediment in surface runoff and drainflow from clayey soils. J. Environ. Q. 30, 589-595. doi: 10.2134/jeq2001.302589x

Uwizeye, A., Gerber, P., Schulte, R. P.O., and De Boer, I. (accepted). A comprehensive framework to assess the sustainability of nutrient use in global livestock supply chains. J. Cleaner Prod.

Van der Straeten, B., Buysse, J., Nolte, S., Lauwers, L., Claeys, D., and Van Huylenbroeck, G. (2010). A multi-agent simulation model for spatial optimisation of manure allocation. J. Environ. Plann. Manage. 53, 1011-1030. doi: 10.1080/09640568.2010.495546

Van Eekeren, N., Bommele, L., Bloem, J., Schouten, T., Rutgers, M., De Goede, R., et al. (2008). Soil biological quality after 36 years of ley-arable cropping, permanent grassland and permanent arable cropping. Appl. Soil Ecol. 40, 432-446. doi: 10.1016/j.apsoil.2008.06.010

Van Orshoven, J. Terres, J-M., and Tóth, T. (2012). Updated Common BioPhysical Criteria to Define Natural Constraints for Agriculture in Europe: 
Definition and Scientific Justification for the Common Biophysical Criteria. Ispra: European Commission Joint Research Centre. Available online at: https://ec.europa.eu/jrc/sites/default/files/lbna25203enn_.pdf

Vrebos, D., Staes, J., Struyf, E., Van Der Biest, K., and Meire, P. (2015). Water displacement by sewer infrastructure and its effect on the water quality in rivers. Ecol. Indic. 48, 22-30. doi: 10.1016/j.ecolind.2014.07.046

Wagg, C, Bender, S. F., Widmerc, F, and Van der Heijden, M. G. A. (2014). Soil biodiversity and soil community composition determine ecosystem multifunctionality. Proc. Natl. Acad. Sci. U.S.A. 111, 5266-5270. doi: 10.1073/pnas.1320054111

Wall, D. P., Plunkett, M., and Murphy, P. (2015). "National soil fertility trends," in Proceedings of the Fertiliser Association of Ireland Spring Scientific Meeting 2015 Publication 50, 21-24. Available online at: http://www.fertilizer-assoc.ie/ wp-content/uploads/2015/04/Proc-No-50-2015-FINAL.pdf

Withers, P. J. A., and Haygarth, P. M. (2007). Agriculture, phosphorus and eutrophication: a European perspective. Soil Use Manage. 23, 1-4. doi: 10.1111/j.1475-2743.2007.00116.x

Ye, L., and Van Ranst, E. (2009). Production scenarios and the effect of soil degradation on long-term food security in China.
Glob. Environ. Change 19, 464-481. doi: 10.1016/j.gloenvcha.2009. 06.002

Zhao, G., Webber, H., Hoffmann H, Wolf, J., Siebert, S., and Ewert, F. (2015). The implication of irrigation in climate change impact assessment: a European-wide study. Glob. Change Biol. 21, 4031-4048. doi: 10.1111/gcb. 13008

Conflict of Interest Statement: The authors declare that the research was conducted in the absence of any commercial or financial relationships that could be construed as a potential conflict of interest.

Copyright (c) 2015 Schulte, Bampa, Bardy, Coyle, Creamer, Fealy, Gardi, Ghaley, Jordan, Laudon, O'Donoghue, Ó'hUallacháin, O'Sullivan, Rutgers, Six, Toth and Vrebos. This is an open-access article distributed under the terms of the Creative Commons Attribution License (CC BY). The use, distribution or reproduction in other forums is permitted, provided the original author(s) or licensor are credited and that the original publication in this journal is cited, in accordance with accepted academic practice. No use, distribution or reproduction is permitted which does not comply with these terms. 